\title{
The Aghlabids and their Neighbours: An Introduction
}

Glaire D. Anderson, Corisande Fenwick and Mariam Rosser-Owen

This book takes an interdisciplinary and trans-regional approach to the Aghlabid dynasty and ninth-century North Africa, to highlight the region's important interchange with other medieval societies in the Mediterranean and beyond. It comprises new invited essays alongside revised versions of select papers presented at the symposium, "The Aghlabids \& their Neighbors: Art \& Material Culture in Ninth-Century North Africa," held in London in May 2014, under the aegis of the University of North Carolina at Chapel Hill. ${ }^{1}$ This event was originally intended as a small interdisciplinary workshop on the history and material culture of the Aghlabid dynasty of Ifrīqiya and their immediate neighbours in the region but rapidly became a larger event when we realised the scale of scholarly interest in the topic. The workshop brought scholars together from different national as well as disciplinary traditions to consider the Aghlabids and their neighbours, with the aim of moving towards a more integrated understanding of this crucial dynasty and period within the Islamic world. Our stated aim in the Call for Papers was to consider North Africa not as a peripheral frontier whose artistic production was inferior to or derivative of trends in the 'Abbasid heartlands of Iraq and Egypt, which is how it has long been situated in the history of Islamic art, but as one of the vibrant centers of the early medieval Dar al-Islam. In doing so, we hoped not only to re-evaluate problematic yet persistent notions of the region's peripherality in Islamic (art) history and archaeology, but also to illuminate processes of acculturation and interaction between ninth-century North Africa, Iberia, Sicily/Italy, and other regions. These same hopes inform the production of this volume, which we hope will stand as a state of the question on the Aghlabids and their material culture at this academic moment, as well as proposing new directions for future study.

\section{The Aghlabids and North Africa}

The Muslim conquest of the Maghreb was notoriously long and contested. ${ }^{2}$ Neither the Umayyads nor the Abbasids ever managed to establish firm control over North Africa, and the eighth century was characterized by repeated rebellions and revolts of both the local Berber populations and rival factions in the Muslim armies (the jund). In 800, the caliph Harun al-Rashid (r. 786-809) appointed Ibrahim al-Aghlab hereditary amir of Ifrīqiya. Ibrahim's ancestors originally hailed from northern Arabia and had participated in the conquest of Khurasan, where they subsequently established themselves. Ibrahim's arrival in North Africa was part of a series of 'Abbasid gubernatorial appointments of Arabs from Khurasan, including the Muhallabids, which gave rise to the widespread use of the nisba alkhurasani throughout the medieval period. ${ }^{3}$ Ibrahim and his successors quelled the rebellious jund and Berber tribesmen, and established what was to be the first autonomous state within the Abbasid caliphate.

\footnotetext{
${ }^{1}$ See the conference website with programme and audio recordings: http://aghlabid.web.unc.edu/program/

${ }^{2}$ Fenwick, "Arab Conquest".

${ }^{3}$ On the origins of the Aghlabids, see Talbi, L'émirat aghlabide, PP.
} 
This state was centered on Kairouan and the palatial cities of al- 'Abbāsiyya (founded 800) and Raqqada (founded in 876) in Ifrīqiya proper - roughly what is now modern Tunisia, eastern Algeria and western coastal Libya. At its peak, under Ibrahim II (r. 875-902), the reach of the Aghlabids extended far beyond Ifrīqiya to Sicily, the Italian mainland, Malta, Sardinia and Corsica. Aghlabid interest sometimes equated to conquest and direct rule, as in the case of Sicily, which proved to be an important counter in diplomatic negotiations with Byzantine Italy. ${ }^{4}$ More often, however, it was limited to raids on the islands and shores of the central Mediterranean launched from their ports in Sousse and Tunis. They even sailed up the Tiber and sacked Rome in 846. It was within this Mediterranean maritime context that the Aghlabid rulers of North Africa defined their position against the Byzantines who still held much of Italy and Sicily, as well as their rivals, the Umayyads in al-Andalus and the Tulunids to the east.

The Aghlabids were not the only ones to lay claim to North Africa. Several decades earlier, new embryonic Muslim states had emerged in the uplands of the Aurés, the pre-desert and Sahara and above all western Morocco: the Barghawata in (158/744); Rustamids (160/776); Idrīsids (173/788) and the Sufrites of Sijilmasa (140/758). The forms of these states varied depending on local circumstances. Sometimes, as with the Idrīsids of central Morocco, incomers from the Islamic East were involved in these nascent processes of state formation. ${ }^{5}$ The kharajite Rustamid state based at Tāhert (western Algeria) was also established by a Persian missionary, 'Abd al-Rahmān b. Rustam of the Ibadi tradition. ${ }^{6}$ Their area of influence stretched to Jerba, Djebel Nafusa and the Fazzan. The relations of these different groups with the Aghlabids were equally varied. Sometimes allied or at war with the Aghlabids, their rulers used a common Muslim rhetoric of power to legitimize their rule

Whilst the Aghlabid amirs never ceased to acknowledge the sovereignty of Baghdad, they were independent in all but name and it would be unwise to think of the Aghlabids as an 'Abbasid vassal state, a notion that Hugh Kennedy's essay helps to nuance. Like the Abbasid caliphs, the Aghlabid amirs minted gold dinars, appointed their own officials, and built new royal towns to house themselves and their retinue - Abbasiyya in 800, which was later replaced by Raqqada in 876. The Abbasids were not part of the decision making process in Aghlabid politics, and there were probably local political reasons why, for example, the name of the Abbasid caliph rather than that of the Aghlabid amir is inscribed in the foundation text at the Zaytuna mosque in Tunis. ${ }^{7}$ Rather than thinking about the formation of the Aghlabid state in terms of a reaction to the disaggregation of the Abbasid empire, Annliese Nef has suggested thinking instead about the construction of a new imperial dynamic in the western Mediterranean. ${ }^{8}$ As she shows in her contribution, this is exemplified by Aghlabid activities vis-à-vis Sicily, which formed the heart of their ambitious campaign against Byzantium. Whereas the Arabs who conquered Ifriqiya in the late 7th century had no use for Carthage as

\footnotetext{
${ }^{4}$ Nef, "Comment les Aghlabides ont décidé". See also, Amari, Storia dei Musulmani.

${ }^{5}$ Cressier, "Urbanisation"; Fentress, this vol.

${ }^{6}$ See Savage, Gateway to Hell; Prevost, L'aventure Ibādite; Aillet, “Tāhart et les origines de l'imamat rustumide".

${ }^{7}$ On which see Golvin, Essai sur l'architecture religieuse musulmane, 153.

${ }^{8}$ Tillier and Nef, "Le Polycentrisme dans l'Islam Médiéval".
} 
a capital, because it was exposed to raids by the still-powerful Byzantine navy, and built their capital at Kairouan, a safe distance of two days march from coast, the Aghlabids expressed a new power and confidence by taking to the sea. ${ }^{9}$ We see the same imperial dynamic in city foundation and monumental architecture. The Aghlabid emirs, like the Abbasid caliphs in Baghdad, were great builders. For themselves, the new rulers built the new palace city of al'Abbāsiyya in 184/800 named in honour of the 'Abbāsids, later supplanted by the foundation of Raqqada in 264/877. Congregational mosques were built in some of the major towns of Ifrīqiya, many of which still survive today in their ninth-century form. Massive town walls were built in stone and pisé to protect the largest cities, as well as a line of fortifications (ribāt) along the coastline at such regular intervals that it reportedly only took one night to dispatch a message from Ceuta in Morocco to Alexandria in Egypt. ${ }^{10}$ These grand monuments, with their use of spolia from nearby Roman and Late Antique sites, show a supreme self-confidence.

The long Aghlabid century was famously described as a golden age by Georges Marçais. ${ }^{11}$ Ninth-century Ifrīqiya was renowned for its agricultural productivity, raw resources (gold, salt, precious metals) and artisanship. This wealth underwrote an economic boom. Kairouan became one of the most important centres of religious and judicial scholarship and intellectual exchange in the dar al-Islam. ${ }^{12}$ Under the Aghlabids, it saw considerable activity amongst religious scholars such as Asad Ibn al-Furat (141/759-213/829) and Sahnūn ibn Sa ${ }^{e} \overline{1} d$ (159/776-239/854), the latter of whom compiled the teachings of Mālik ibn Anas in the Mudawwana which became the main reference for Mālikism in North Africa. Beyond Kairouan, the cities and countryside were transformed by the construction of new forms of monumental architecture as well as by urban growth, a surge in rural settlement and investment in infrastructure. ${ }^{13}$ High-prestige items such as ornate glazed ceramics, metalwork and textiles circulated, and trade and commercial networks flourished linking North Africa to sub-Saharan Africa, Europe and Iraq. The Aghlabids and their neighbouring states were major conduits of the slave trade - both the white slave trade, which linked North Africa with Iberia, the major marketplace, but further afield to the Carolingian empire and central Europe, from where the slaves were sourced; and the black slave trade, via the trans-Saharan trading networks. ${ }^{14}$ North Africa provided an important transit point for raw materials like gold, ivory, salt and was an key producer of bulk staple goods like olive oil and grain, but its artisans and patrons also made sophisticated artefacts that had a widely dispersed market. The sorts of goods that were exported from Aghlabid Ifrīqiya in scale - whether luxury items such as slaves, gold or ivory, or staples like olive oil, grain and textiles - are not always easy to trace in the historical or archaeological record, but we must not forget that they underpinned the Aghlabid 'golden age'.

\footnotetext{
${ }^{9}$ Goitein, "Medieval Tunisia", 309.

${ }^{10}$ Ibn Khaldun, Berberes T. IV, 429.

${ }^{11}$ Marçais, La Berbérie Musulmane, 55.

${ }^{12}$ See Bahri, Les hommes du pouvoir.

${ }^{13}$ Fenwick, "Early Medieval Urbanism".

${ }^{14}$ Gaiser, "Slaves and Silver".
} 
It is all the more surprising, then, that ninth-century North Africa continues to be so systematically ignored in accounts of the early Islamic world, whether they be historical, arthistorical or archaeological. This lacuna cannot be explained on the grounds by which it is so often justified: an absence of source material. For the advent of the Aghlabids coincides with a marked surge in the amount and quality of evidence available to scholars after the late seventh and eighth centuries. ${ }^{15}$ Historians can draw upon a wealth of conquest accounts, geographies, judicial accounts, religious tracts, biographical dictionaries, while archaeologists and art historians can more easily identify ninth-century objects and buildings by the spread and adaptation of new forms and techniques from the wider Islamic world. The neglect can also not be wholly explained away by the difficulties of conducting research across such a vast area that encompasses multiple modern nation-states with very different histories of scholarship. A far greater problem is the continued dominance of centrist narratives of the Abbasid world at the expense of those areas on the Mediterranean edges. ${ }^{16}$ This presents perhaps the main reason for the neglect of studies of this region. North Africa and the Islamic West are all too often seen as peripheral to the 'Abbasid heartlands of Iraq and Egypt, and it is this judgement that explains the small part North Africa plays in scholarly accounts of the medieval world. However, as this volume illustrates vividly, North Africa was plugged into an international trade network in every direction, and had both the wealth to bring luxury commodities from far afield, and a sophisticated market willing to buy them. However North Africa was not just a recipient of exotic imports from elsewhere, the region also generated luxuries that other people wanted as well as staples that other peoples needed.

Medieval Tunisia was the "hub of the Mediterranean", and Kairouan its most important trunk point. ${ }^{17}$ Its geographical position was exceptionally favourable, lying halfway between Morocco and Egypt, at the very centre of caravan traffic between (on the one hand) western North Africa and the countries south of the Sahara, and (on the other) Egypt and its eastern and southern neighbours. Sicily, the bridge to Europe, could be reached even in small boats. Tunisia's central position in the Mediterranean made it the natural entrepôt for goods from east and west, especially since at this period trading ships sailed by cabotage and did not undertake direct long-haul voyages across the Mediterranean. Sicily (and to some extent the maritime states of Italy) and Tunisia acted as distribution centres along these trading networks. While no Geniza documents survive from the 9 th century and only a few from the 10th, during the period 1000-1150, Tunisian merchants appear in the Geniza papers as predominant in both Mediterranean and Indian Ocean trade. The Geniza archive also shows that Kairouanese Jews were in far closer contact with the Jewish academies of Baghdad than those of Jerusalem, a degree of contact which has an interesting bearing on the presence of luxury objects from Abbasid Iraq in Aghlabid contexts (see below).

\footnotetext{
${ }^{15}$ On the problem of archaeological visibility for the eighth century, see Fenwick, "From Africa to Ifrīqiya", $11-14$.

${ }^{16}$ Rosser-Owen "Mediterraneanism"; Anderson "Integrating the Medieval Iberian Peninsula".

${ }^{17}$ See the seminal but neglected article of Goitein, "Medieval Tunisia", esp. 308-313.
} 
The Aghlabids were a powerful and expansive Mediterranean dynasty with a taste for luxury goods and artistic patronage; but all too often this period is considered as one which did not produce anything of material value or artistic merit. This is self-evidently not the case when we look closer. Already by the mid-eighth century, we know of the existence of a dar al-tiraz in Ifriqiya during the reign of Marwan II (r. 744-750), thanks to the contents of the embroidered inscription on the so-called "Marwan tiraz", today in the V\&A. ${ }^{18}$ The silk textile to which the inscription was added was probably imported into Ifriqiya from Central Asia, indicating that already at this date Abbasid-appointed governors in North Africa were receiving the most luxurious commodities from the Islamic East. However, the existence of a dar al-tiraz in Ifriqiya - which is only known from this inscription, and again shows the historical importance of looking to the material record - indicates the continuing importance of sericulture and silk production in Ifriqiya. This had a long tradition, pre-dating the Islamic period but obviously continuing to flourish under Muslim patronage, though very early examples do not survive in abundance. Luxury silk textile production and trade was one of the most significant means by which the regions of the western Mediterranean became interconnected in the mid-tenth century, when the Amalfitans began trading Ifriqiyan and Byzantine silks in Umayyad Córdoba. ${ }^{19}$ It is no coincidence that alum, the important mordant for fixing dyes in silk textile production, was another commodity sourced from trans-Saharan trade. $^{20}$

And yet, when it comes to cultural production and innovation, Kairouan is traditionally considered an outpost of 'Abbasid imperial power (particularly in art history), locating it within an out-moded centre:periphery framework. We see this particularly in the study of ceramics, especially in what might be dubbed the "orientalisation myth". This "myth" holds that the use of a yellow ground in ceramics in Ifriqiya and Sicily before the 10th century is somehow connected to the simultaneous but equally odd use of yellow in the ceramics attributed to Nishapur. The fat-bodied birds which appear in the "jaune de Raqqada" and which characterise the "giallo di Palermo" have also been associated with the distinctively naive figurative style of Nishapur ceramics. No examples of Nishapur ceramics imported into Ifriqiya are attested as a means by which this connection might have happened - indeed, Nishapur ceramics do not seem to have been widely exported outside their region. This shared aesthetic is implicitly attributed to a passive absorption by North African potters of a dominant style favoured in the Abbasid centre. These issues are considered in more detail below, in the overview of the book's ceramics section (Section 3), but here it is important to note that we should revise our way of thinking in terms of passive "influences" absorbed by the regions because they were blindly following the fashions of the imperial "centre", and begin to think in more nuanced ways, especially in terms of agency and signification on the part of local patrons.

\footnotetext{
${ }^{18}$ Moraitou, Rosser-Owen and Cabrera, "Fragments of the So-Called Marwan Tiraz".

${ }^{19}$ Metcalfe and Rosser-Owen, "Forgotten Connections?". See also Isabelle Dolezalek's essay in the same volume, "Textile Connections?"; and the article by Skinner, "Amalfitans".

${ }^{20}$ Guérin, "Avorio d'ogni ragione", esp. 165-173.
} 
Famously, during the Aghlabid period, teak was imported from Abbasid Iraq to furnish the wood for the minbar and original maqsura at the Great Mosque of Kairouan, as were 139 lustre tiles to adorn the mosque's refurbished mihrab. Recent scientific analyses have definitively established the Iraqi provenance of these tiles, while Jonathan Bloom's essay in this volume looks to the carved marble panels that line the mihrab niche, considering the possibility of the Andalusi origins of the marble, their carver, and the techniques employed to carve them. The fact that these luxury objects, materials and artisanal expertise may have been imported by the Aghlabids does not diminish the significance of their presence in Kairouan. At a slightly later period, the debates over the place of production of the Blue Qur'an fit neatly within this model of luxury commodities of the highest quality reaching Ifriqiya: if imported from Baghdad, as Alain George has argued, this speaks to Kairouan's far-flung international connections; if produced locally, as Jonathan Bloom has argued - and to which Cheryl Porter's article in this volume aims to bring practical supporting evidence - it argues for the high level of artistic production that was attained in Ifriqiya by the middle of the tenth century. In both cases, it reflects the importance and wealth of local patronage power in Ifriqiya. ${ }^{21}$

Aghlabid rule in Ifriqiya lasted little more than a century. In 909 the Aghlabids were overwhelmed by the strength of a new North African empire - that of the Fatimids - who quickly swept through North Africa and created a Shì'i caliphate in the southern Mediterranean to rival that of the Sunnī Abbasids in the Middle East. Indeed the importance of the Aghlabids has been overshadowed by the Fatimids and the perhaps more attractive debate about the competition between the three great caliphates of the tenth century (once the Umayyads in al-Andalus had thrown in their claim as well). Fatimid studies - both historically and art historically - have been dominated by their Egyptian period, which underplays the importance of the North African role both before and during their dynasty. While the Ifriqiyan phase is often viewed merely as a "preparation phase", 22 it is important to acknowledge not just the historical fact of the Maghrebi origins of the Fatimids, but also to consider the role of Ifrīqiya in the formation of Fatimid art and architecture in later centuries. ${ }^{23}$ Ifrīqiya would not have been so attractive to the Fatimids if it had not been made rich and powerful by the Aghlabids. Dominique Valérien recently noted that key to Fatimid policy was their imposition in the Aghlabid sphere of influence, controlling Mediterranean ports and turning towards the sea. ${ }^{24}$ Like the Aghlabids, they did not turn their back on the Sahara: for two decades after the foundation of Cairo they made constant attempts to win territory - and thus access to trans-Saharan trade goods - in the Maghrib al-Aqsa. ${ }^{25}$ In many instances, the Fatimids literally built on Aghlabid foundations, as Patrice Cressier has shown for Sabra-Mansuriyya, the Fatimids refurbished the Aghlabid aqueduct of Shirishara to bring water from a natural spring that had already been exploited by the Romans. ${ }^{26}$ Other features

\footnotetext{
${ }^{21}$ George, "Calligraphy, Colour and Light"; Bloom, "The Blue Koran Revisited".

${ }^{22} \mathrm{Nef}$, "La délégation politique", 53-54.

${ }^{23}$ Bloom, Arts of the City Victorious, Chapter 2, "Fatimid Art in North Africa"; Brett, The Rise of the Fatimids.

${ }^{24}$ Valérian, "Les ports d'Ifrīqiya".

${ }^{25}$ See Brett, "The diplomacy of empire".

${ }^{26}$ Cressier and Triano, "Madinat Al-Zahra". See also Solignac, Recherches.
} 
at Sabra, such as stone merlons, appear to have been reused from Aghlabid buildings. While the Fatimids adopted new architectural forms, they relied on local construction methods. The same may be said of stylistic features, such as the early appearance of vegetal motifs and floriated inscriptions in Aghlabid tombstones, which are seen in the carved plaster revetments from Sabra but flourish once the Fatimids reached Egypt; or technologies, such as the development of lustre ceramics: the discovery of a lustre kiln at Sabra has still not received the attention it deserves (though we eagerly await the publication of the scientific analyses of the Sabra ceramics by Yona Waksman). ${ }^{27}$ The Fatimids, we would suggest, cannot be understood without looking back to the history and material culture of their precursors, the Aghlabids.

The challenge, then, in understanding the long ninth century in North Africa is that of locating the Aghlabids and their neighbours within broader historical narratives and theoretical debates. On one level, Aghlabid rule in North Africa must be understood within the framework of the Abbasid caliphate, now based in Baghdad, and the emergence of a range of other vassal states on its edges like the Tahirids in Khurasan (established 204/820), Ahmad ibn Adad in Tabaristan (205/820), the Saffarids of Sijistan (253/867), the Tulunids in Egypt (254/868), and the Samanids of Transoxiana (261/874). Like these other border regions, ninth-century Ifrīqiya saw the emergence of Muslim elites who saw themselves as independent dynastic rulers, whilst being part of an Abbasid political, economic and cultural koine. On another level, it is essential to examine the Aghlabids within their Mediterranean context. Beyond the battle for Mediterranean supremacy between the Byzantines and the western Islamic states, the ninth century is characterized by a remarkable upsurge in the movement and circulation of traders, slaves, relics and goods between Christian and Islamic territories. ${ }^{28}$ Finally, the Aghlabids must be considered within their African setting. Like their rivals in the mountainous and Saharan fringes of Ifriqiya, they justified their sovereignty within a Muslim framework and the new economic, social and intellectual opportunities that came about in the new Islamic world-system linking the Maghreb into a network that connected sub-Saharan Africa, the Mediterranean and East Asia. It is only by tracing these different connections - caliphal, Mediterranean and African - that the history and material culture of ninth-century Ifrīqiya can be adequately understood.

\section{Historiographical considerations}

North Africa played a key role in the medieval world system, linking the Dar al-Islam with sub-Saharan Africa and Europe. As Sarah Guérin commented to Rosser-Owen during the planning of their jointly organised colloquium, ${ }^{29}$ North Africa was a "hinge not a fringe". In recent years, economic and social historians have redefined the Sahara as a bridge rather than a barrier, between the verdant West African entrepôts and the Mediterranean world of markets and consumers. Yet the connection was not direct. The important territories -

\footnotetext{
${ }^{27}$ On the stucco, see Barrucand and Rammah, "Sabra al-Mansuriyya".

${ }^{28}$ McCormick, Origins; Conant, "Europe and the African Cult."..

29 "Beyond the Western Mediterranean: Materials, Techniques and Artistic Production, 650-1500", The Courtauld Institute of Art, London, 20 April 2013.
} 
economically, politically and socially - of North Africa served as the gateway between the Dar al-Islam and Europe. Nevertheless, North Africa's pivotal role in the middle ages has received little attention from the broader fields of Islamic art history, archaeology and history, especially in the Anglophone world. There has been a more continuous study of North Africa and the western Mediterranean in Francophone scholarship, and to a lesser degree in Spanish and Italian scholarship where several attempts have been made in recent years to draw together scholarship on different topics from the Islamic West, particularly through the auspices of the Casa de Velázquez and the École Française de Rome. ${ }^{30}$ However, even within this academic tradition, the Islamic West is seldom integrated into 'mainstream' scholarship on the Mashriq and the heartlands of the caliphate.

The sidelining of the Aghlabids, and medieval North Africa as a whole, has arisen both from the dominance of centre:periphery models established during the European colonial period, and from the continued ghettoization of Islamic scholarship into regional schools of research that rarely communicate with one another. Anderson has recently noted the problems raised by the fact that the Great Mosques of Kairouan and Cordoba - two of the most important religious foundations in the medieval Islamic West (the third being alQarawiyyin in Fes) - practically contiguous, with coeval building programmes, are habitually studied in Anglophone Islamic art survey texts and courses as if they were in different worlds. ${ }^{31}$ Kairouan is situated within the Abbasid architectural sphere of Iraq and Egypt, while Cordoba forms a brief phase within a ghettoised and usually diachronic chapter on 'the Islamic West'. As she has emphasised, a more regionally-specific framework would invite a study of the connections between these monuments, rather than insisting on perceiving artistic change as a passive reflection of caliphal influence. As yet, comparative and transregional approaches have not been prioritised within Islamic art, history and archaeology but there is an increasing trend in Mediterranean and medieval studies in this direction. The recent trend in scholarship to open up the study of the Mediterranean region invites a fuller and more holistic consideration of North Africa, as Rosser-Owen has already discussed elsewhere. ${ }^{32}$ Comparative Mediterranean approaches seek to investigate interconnectivity in an "impartial" way, as encouraged by Horden and Purcell in The Corrupting Sea; indeed, these scholars specifically advocate that 'Mediterranean studies' should 'impartially embrace North Africa and the rest of the Middle East'. ${ }^{33}$ Similarly, the call for the study of the 'global middle ages' seeks to de-centre the traditional European focus of medieval studies and to emphasize connections and networks between different states, regions and places. ${ }^{34}$ The advantage of adopting a properly 'impartial' Mediterraneanist or 'global' approach to the medieval world is that it forces scholars to give due prominence to North Africa. This is not wholly unproblematic: one should be careful not to think of North Africa solely as a Mediterranean-facing region, when it is just as important to consider its relationships with the

\footnotetext{
${ }^{30}$ See most recently Senac Histoire et archéologie; Nef and Ardizzione, Les dynamiques de l'Islamisation;

Valérian Islamisation et arabisation.

${ }^{31}$ Anderson, "Integrating the Medieval Iberian Peninsula".

${ }^{32}$ Rosser-Owen, "Mediterraneanism".

${ }^{33}$ Horden and Purcell, The Corrupting Sea, 17.

${ }^{34}$ Holmes and Standen, "Defining the Global Middle Ages"
} 
Sahara, or the rest of the African continent, or the Atlantic in the case of Morocco. Nor indeed, should one examine North Africa only in terms of its connectedness or relationship with Europe or Byzantium or the Caliphate. Ultimately, of course, we hope that the archaeology, art and architecture of North Africa in the Islamic period will be considered on its own terms.

It is not without its challenges to conduct research across a vast geographical area that encompasses multiple modern nation-states with very different histories of scholarship and experiences of European nationalism or colonial rule. But the neglect of the Aghlabids cannot be wholly blamed on these difficulties. The almost complete absence of North Africa from Islamic art survey texts produced in the Anglophone world reflects the endurance of colonial and postcolonial biases of the early twentieth century, which saw political, social and cultural change as driven by external "influence" from the centre of the caliphate. This region was considered as provincial by 19th- and 20th-century historians working within their own colonialist framework, and this legacy still underpins scholarly approaches to the Mashriq and the Islamic West today. The bulk of scholarship on medieval North Africa was produced in the first half of the twentieth century by a relatively select group of French scholars working across the disciplinary divisions that to a large extent still define our contemporary academic contexts. Some of the major figures include William (1872-1956) and Georges Marçais (1876-1962), Évariste Lévi-Provençal (1894-1956), Alexandre Lézine (1906-1972), Lucien Golvin (1905-2002) and Henri Terrasse (1895-1971). These and other scholars of their generation, working primarily in France and Spain, moved between European and North African institutions such as the Institut des hautes études marocaines in Rabat, Morocco; the Université d'Alger in Algiers, Algeria; and the Sorbonne in Paris, France. These men were not just scholars sitting in libraries, but active hands-on readers of inscriptions or restorers of crumbling medieval buildings. Their resulting publications, museum activities, and teaching established the scholarly foundation for studies of medieval Islamic North Africa, which scholars have continued to build upon since.

Indeed, the pioneering scholarship undertaken in the first half of the $20^{\text {th }}$ century remains the essential point of reference today. Little has been published on Aghlabid architecture, beyond descriptions and plans by William Marçais, Alexandre Lezine and H.A.C. Creswell of the most famous monuments- the great mosques of Kairouan, Sousse and Tunis and the ribats of Sousse and Monastir - most of which were published in the first half of the $20^{\text {th }}$ century. ${ }^{35}$ Only eight monuments - four congregational mosques of Kairouan, Sousse, Tunis and Sfax, two neighbourhood mosques in Kairouan and Sousse and the ribats of Sousse and Monastir have received sustained scholarly attention. The standard approach has been typological, that is, scholars have studied mosques and ribats according to ground plan, divisions of exterior and interior space, and other formal criteria. These architectural studies were occasionally supplemented by small archaeological sondages aimed at clarifying construction dates -often under the auspices of Alexandre Lezine. ${ }^{36}$ Far rarer were large-scale

\footnotetext{
${ }^{35}$ Marçais, L'architecture. Lézine, Architecture; Creswell, Early Muslim Architecture.

${ }^{36}$ Lézine, Le Ribat De Sousse.
} 
excavations of medieval sites. Aside from William Marcais' excavations at 'Abbāsiyya in the 1920s and finds (occasionally and not systematically) noted from the widescale clearances of sites to their early Roman levels, the study of ninth-century Ifrīqiya was based on the Arabic sources and architectural studies of buildings. ${ }^{37}$ After Tunisian independence in 1956, the focus on monument and urban sites continued: M. Chabbi dug a few years later at Raqqada, excavating the palace, where the ceramics published by Daoulatli reveal the emphasis on beautiful objects. ${ }^{38}$ In subsequent years, further excavations have taken place at various ribats and mosques alongside restorations, if rarely published. Perhaps most frustrating of all, the 1950s excavations in the courtyard of the Great Mosque at Kairouan and the supposed location of the dar al-imara have never been published. As Patrice Cressier puts it, here we have an archaeology of antiquarians, inherited from the $18^{\text {th }}$ century. ${ }^{39}$

After independence, the most important new contribution to the subject came in the historical field from the doyen of Tunisian history: Mohamed Talbi's monumental L'émirat aghlabide, published in 1966, which replaced Maurice Vonderheyden's (1927) La berbérie orientale sous la dynastie des Benou'l-Arlab as the authoritative account of the Aghlabids and the ninth century. ${ }^{40}$ In this volume and a series of other significant contributions on Aghlabid biographies, architecture, theology, the economy and Christianity, he purposely set out to tell an histoire événementielle of the period based on a close reading of the sources in order to challenge the more popular longue durée approach of the period. ${ }^{41}$ These works have yet to be exceeded and stand as eloquent testament to the quality and depth of his scholarship and his unmatched grasp of the evidence, both textual and archaeological. In some respects, however, L'emirat aghlabid is a history of its time and composed when revisionist historians were rewriting the history of the Maghreb in the wake of the decolonisation of North Africa in the 1960s and 1970s. ${ }^{42}$ As a result, some of the interpretations are imbued with a nationalist reading of the evidence, such as Aghlabid interest in Sicily which he viewed as 'foreign' policy rather than an integral component of their state-building strategy, a view that Annliese Nef challenges in this volume. Nevertheless, if certain aspects of Talbi's interpretative framework are now being modified, his valuable works remain the essential starting point for any account of the Aghlabids and ninth-century North Africa.

Our understanding of Aghlabid Ifrīqiya has developed substantially in the last few decades driven primarily by the meticulous research of Tunisian scholars. Fathi Bahri has unravelled the complexities of Aghlabid administrative, military and judicial institutions and the structure of the ruling elites. ${ }^{43}$ Critical re-readings of both the documentary and archaeological evidence by scholars like Faouzi Mahfoudh, Néji Djelloul, Ahmed El Bahi and Muhammed Hassen has refined our understanding of urbanism, the building histories of

\footnotetext{
${ }^{37}$ Marçais, "Fouilles à Abbâssîya".

${ }^{38}$ Chabbi, "Raqqada"; Daoulatli, " Le Jaune De Raqqada".

${ }^{39}$ Cressier, "Ville Médievale Au Maghreb".

40 Talbi, L'Émirat aghlabide.

${ }^{41}$ Talbi, Biographies aghlabides; Études d'histoire ifriqiyenne; "L'Ifriqiya à l'époque aghlabide"; "Theological Polemics"; "Le christianisme maghrébin"; "Law and Economy".

${ }^{42}$ See essential remarks on its approach and contents in Wansburgh "On recomposing the Islamic History".

${ }^{43}$ Bahri, Les hommes du pouvoir..
} 
Aghlabid mosques, ribat and other buildings as well as our understanding of the historical geography of Ifrīqiya in the ninth and tenth centuries. ${ }^{44}$ Our understanding of ceramics, numismatics and epigraphy has been transformed by the rich studies of Adnan Louhichi, Lofti Abdeljouad and Abdelhamid Fenina. ${ }^{45}$ Much of this work, however, is published in French or Arabic in journals, books or dissertations that are hard to obtain outside of Tunisia and it has not had the recognition that it deserves by Anglophone scholars.

Medieval archaeology is not so well developed in North Africa as Roman archaeology, but in recent years, too, a surge in archaeological excavations and field-surveys are beginning to transform our understanding of this pivotal period. ${ }^{46}$ Equally encouraging is the increasing interest of classical archaeologists in the later medieval history of many Iron Age and Roman sites (e.g. Chemtou, Utica, Carthage, Uchi Maius, Althiburos). Importantly, these excavations have begun to produce typologies for early medieval ceramics, which complements the work conducted by scholars such as Adnan Louhichi and Giovanna Vitelli on extant collections of medieval ceramics in Tunisian museums, which are often unstratified and lack provenance. ${ }^{47}$ In the next decade, we can expect tighter ceramic chronologies which will increase our ability to identify and closely date ninth-century activity. These campaigns are also active at publishing their findings and reaching out to the international scholarly community to share their research.

Archaeological developments elsewhere in North Africa and the central Mediterranean have significantly improved our understanding of the Aghlabids and their neighbours in recent years. Our best information for North Africa comes from Morocco and Libya, where field-survey and excavations at sites such as Sijilmasa, Nakur, Walīla, the Jebel Nafusa and the Libyan Fazzan has revealed much about early Islamic urbanism, the formation of early Berber/Arab splinter states and long-distance trade as we see in the contributions to Section Four. ${ }^{48}$ Algeria is the least well served of the North African countries in terms of archaeology: excavations at the Rustamid capital of Tahert are only briefly described in two short articles and have never been fully published. ${ }^{49}$ Few projects have been conducted there since the important excavations at Sétif in the 1980s and this has repercussions for our understanding of the western flank of the Aghlabid state and key cities such as Tobna, Tébessa, Constantine, Biskra and Mila as well as our knowledge of the Rustamids and the Ibadi network. ${ }^{50}$ Beyond North Africa, the surge in interest in Byzantine and Islamic Sicily and al-Andalus since the 1980s is well known and as several contributions show, the growing body of historical and archaeological scholarship is not only transforming

\footnotetext{
${ }^{44}$ Mahfoudh, Architecture; Djelloul, al-Ribāțāt al-bahrīya; Hassen, "Les Ribâț̣"; El Bahi, Susa wa 'l-Sahil

45 See for example, Abdeljouad Inscriptions arabes; Fenina et alii, Numismatique et histoire; Louhichi,

Céramique Islamique de Tunisie.

46 See Fenwick "From Africa to Ifrīqiya" for an overview.

${ }^{47}$ E.g. Louhichi, Céramique Islamique de Tunisie, Vitelli Islamic Carthage. For a status quaestionis of medieval ceramics, see Cressier and Fentress La céramique maghrébine.

${ }^{48}$ In addition to the research programmes described in Section 4, see also Cressier, 'Urbanisation', Benco,

Anatomy of a Medieval Islamic Town;. Ennahid, Political Economy; Prévost, Les mosquées ibadites.

${ }^{49}$ Cadenat, "Recherches À Tihert-Tagdempt"; Marçais, "Tihert-Tagdempt,".

50 See Khelifa "L'urbanisation" for the most recent overview. On Sétif, see Mohamed and Fentress, Fouilles de Sétif.
} 
our understanding of these regions but also their economic, social and intellectual links with Ifrīqiya and the Maghreb al-Aqsa. ${ }^{51}$

The publication of this volume thus comes at a critical turning point in the study of medieval North Africa and the Islamic West. Nevertheless, there remain very real difficulties for North African and overseas researchers alike. For many of our North African colleagues, the biggest challenges are funding for research projects, up-to-date equipment (especially for archaeological fieldwork) and conservation as well as obtaining access to library resources and participation in international conferences. In some countries and regions, security continues to be a significant barrier to conducting research. In Libya, currently a conflictzone, our colleagues are doing their best to protect, record and conserve the country's cultural heritage with only limited resources and at significant risk to the personal safety of themselves and their families. In Libya and elsewhere, the pace of modern development and oil exploitation in the past few decades also poses a serious threat to medieval sites across North Africa, and rescue archaeology projects are rare. Further problems arise on the linguistic front: the majority of research on medieval archaeology conducted by our North African colleagues is published in Arabic or French and is not easily accessed or widely read by many Islamic scholars working outside the region (many of whom do not possess the requisite language skills). Conversely, many North African scholars do not have access to much of the most recent English or European language scholarship on the Islamic world. Fortunately, the rise of online publication and open-access research depositaries is making much of this scholarship available online to a far larger audience which will hopefully encourage new research directions and collaborations that cross-cut these divisions. But the current problems of international mobility across borders - especially into the UK and USA where increasingly strict visa regulations are in place - will continue to mean that the work of North African scholars is not given due attention. ${ }^{52}$

For overseas researchers, the difficulties are centred on access: the dangers of travelling around Algeria, for example, have meant that for two generations sites that have important light to shed on the transmission of styles and technology across North Africa into Italy and Iberia, such as the UNESCO site of the Qal'a of the Banu Hammad, have effectively been dropped from the canon. Political stability remains unpredictable in much of the region after the Arab spring but the fact remains that North African countries, aside from Libya, are now becoming much safer and easier to travel in than other problematic regions where Islamic scholars try to conduct their research. The growth in collaborative excavation projects is already encouraging many European students to focus their research interests on this region, and in so doing, contribute to our understanding of medieval North Africa. However, instability is not the only obstacle to studying this region. Non-Muslims cannot visit the interior of mosques in Morocco and Tunisia, and photography is prohibited in many museums without a permit, especially in Morocco, so that the basic art historical tools of seeing and recording are denied to the interested researcher. Historians and archaeologists are

\footnotetext{
${ }^{51}$ See most recently and with the full bilbliography, Ardizzione and Nef Les dynamiques de l'Islamisation. ${ }^{52}$ Indeed, many of our North African delegates were unable to attend the 2014 workshop in person as the UK embassy took too long to issue the visas, despite the paperwork being submitted months in advance.
} 
better served, but long drawn out and complex bureaucratic arrangements are required to set up fieldwork projects or access archival collections, which takes time and commitment on the part of the researcher, as well as a combination of language skills - at least fluent French, ideally also good North African Arabic - with which most graduate students will not be equipped. Nevertheless, the rewards more than repay the effort.

\section{The Layout of the Volume}

The articles in this collection aim to highlight some of the most recent research on 9th and early 10th-century North Africa, and more broadly to demonstrate the potential of integrating North Africa and the Islamic Mediterranean into broader medieval histories. It should be emphasized from the outset, however, that we make no claim to comprehensiveness in coverage. Indeed, those readers already familiar with North Africa and the Mediterranean in the ninth century will rapidly identify important research problems, neighbouring states, archaeological sites and monuments which have been only treated in passing, or comparative angles that have yet to be explored. Nonetheless, we hope that the chapters that follow will inspire new ideas and research directions for those familiar with the region, as well as introducing current work in the field to those readers more familiar with the world of the Abbasid caliphate or early medieval Europe or with other periods of North African history. Many of the articles here draw on unpublished research, building on studies of unknown or neglected objects and archives, and laying important groundwork for future research. Our approach involves an egalitarian mixture of history, archaeology, and art history - we do not privilege any of these disciplines, each of which enriches and enlightens the others. It also includes the work of scholars from many different regional traditions - North Africa, Europe, the UK and the USA - in order to give a sense of the diversity and richness of research in these different contexts. The different scholarly methods practised in these different regional and disciplinary traditions has the potential to create an unevenness of approach across the volume, which we hope, as editors, to have minimised as far as possible.

The collection is divided into five sections. The first introduces the Aghlabids by dealing with issues of statehood and state-building, politics and power; the second focuses on the monuments they constructed, in particular their religious foundations, as the physical expression of this power. The third section is dedicated to studies of ceramics from within the Aghlabid realm and their close neighbours, studies which raise similar issues of technical transfer, trade, exchange, the mobility of objects and of people. Section four widens out the context yet further, looking to the Aghlabids' neighbours - be they close by, in Jerba, Sicily and southern Italy; or slightly further in the Maghrib al-Aqsa or across the Sahara - and examining their relationships with them. The final section focuses on two manuscripts of the Qur'an to consider the Aghlabids' legacy into the 10th century.

\section{State-building}

Hugh Kennedy considers the Aghlabids as the first independent rulers of Ifrīqiya and thus a key political phenomenon of the early caliphal empire. He explores the origins of the Aghlabid family among the Khurasani army of the early Abbasid caliphate and shows how 
the Aghlabids used their standing in the army and their military connections to build an effective power base in the province. His essay analyzes the processes and meanings of independence that accompanied the political fragmentation of the Abbasid empire, contextualizing these against the North African conquest and occupation. Surveying the historical contours of the Aghlabid state, Mounira Chapoutot's essay also reminds us of its turbulent beginnings and underscores the human actors in its formation: early Abbasid administrators, émigrés from the empire's eastern territories, Berbers, and enslaved/unfree elites who comprised the Aghlabid household and bureaucracy, its system of clientage, and the socio-political structures that connected free, enslaved, and freed men and women. Central to the issue of state formation, as her essay also reminds us, were expressions of Aghlabid ruling identity -- titulature, for instance, as well as material manifestations of that identity, whether at the micro scale in the form of small portable goods (notably robes of honour and other textiles) or at the macro level in architecture and urbanism.

The Aghlabid reach stretched outside North Africa into the central Mediterranean and Annliese Nef argues compellingly that to understand the Aghlabid state and ninth-century Ifrīqiya, we must fully integrate Sicily into scholarly accounts. Her revisionist account argues that Aghlabid raiding against Sicily was not a failed or lengthy conquest - as earlier scholars have suggested - but instead a conscious policy of state-sponsored jihad against Byzantium that took the form of long-term raiding and guerrilla warfare over many decades. Viewing Aghlabid maritime activities in Sicily and indeed the central Mediterranean in this light reminds us that the Aghlabids were very much a maritime state with a Mediterranean vision not simply a North African one. It was on these Aghlabid foundations that the Fatimids built their own Mediterranean empire.

Caroline Goodson's essay turns to the role that urbanism, monumental building and the holy city of Kairouan played in Aghlabid claims to political legitimacy. The Aghlabid rulers invested heavily in improving and monumentalising the urban fabric and infrastructure of Kairouan and other North African cities as well as their own new urban foundations of al'Abbāsiyya and Raqqada as the contributions in Section 2 show. Primarily using written sources, Goodson argues that patronage of religious architecture and urban amenities at Kairouan and in its hinterland was not simply the prerogative of the Aghlabid emirs, but also played a key role in establishing alternative networks of power, piety and allegiance amongst certain urban factions in the ninth century.

Taking a different tack, Dwight Reynolds's essay takes up a fascinating moment of transfer between the Abbasid court and that of the Aghlabids, in the person of arguably the best-known musician and tastemaker in the history of Islamic civilization -- the celebrated Ziryab. Given the fame he attained later in the Cordoban Umayyad court, we seldom consider the import of Ziryab's decision to seek patronage in the Islamic West, rather than in one of the eastern courts. Yet his decision is suggestive, perhaps, that the Aghlabid court had a reputation in Abbasid circles as a patronage centre (medieval musicians, like those of our own time, would presumably have been interested to seek out good gigging prospects, after all). Musical performance emerges here as one important facet in the construction of caliphal court life, in the Islamic West, as in the empire's eastern reaches. Reynolds evaluates the 
historical plausibility of the single known reference to the celebrated musician, Ziryāb, in the Aghlabid court by examining the earliest known references to Ziryāb in the work of Ibn 'Abd Rabbih (860-940) and other early Arabic texts. His analysis illuminates the historical Ziryab at an early stage in his career, alongside what is known about artistic life at the court of Ziyādat Allāh, and thus brings al-Andalus and Aghlabid Tunisia into dialogue in the realm of performing, as well as visual, arts. Methodologically Reynold's use of Arabic adab texts complements the essays that use chronicles, numismatics, and epigraphy as the main textual sources, and it adds music as another realm of sensory importance to round out our archaeological, art historical, and material culture perspectives.

Finally, Abdelhamid Fenina turns to the controversial question of the location and foundation date of the city of al-Abbāsiya. Famously, the written sources recount that when Ibrāhīm b. al-Aglab took power in 184/800, his first action was to build a new city called al-Abbāsiya in honour of the Abbasid caliph. It is perhaps less widely known outside numismatic circles that we possess thousands of coins minted by Abbasid governors in an otherwise unlocated or attested site called al- 'Abbāsiyya from 150/767 onwards. Fenina's critical re-reading of numismatic, textual and archaeological sources draws the attractive conclusion that the multiple "Abbāsiyyas' in the sources were in fact one settlement founded and extended by members of the same family rather than different settlements. The first of these was qasr al- 'Abbāsiyya established on the ruins of qasr al-Mā' founded by al-Aghlab b. Sālim al Tamīmī, a site that continued to be used under later Abbasid governors. It was only when Ibrāhīm b. al-Aglab took charge that this site was transformed into a city by the addition of palaces, mosque and fortifications, and so the al- 'Abbāsiyya celebrated in later accounts was born.

\section{Monuments: the physical construction of power}

The essays in this section highlight the monuments that have earned the dynasty its place in the canon of early Islamic architecture: the Great Mosque of Kairouan is the standard bearer for Aghlabid monumental architecture, so it will come as no surprise that it is the focus of essays by Mahfoudh, Bloom, Picotin and Délery, and Hamdi. Rounding out the focus on monuments are essays on the splendid Zaytuna Mosque of Tunis which is perhaps less familiar than the Kairouan Mosque, but as a nearly contemporary major monument deserves much more attention. While the volume does not include specific articles on other key monuments, such as the Mosque of the Three Doors in Kairouan or the Great Mosques of Sousse or Sfax, these buildings are discussed in other articles, which refer to them and their significance from a wide range of perspectives, encompassing their ornament, their epigraphy and their political motivations. The final essay in this section presents Abdeljouad Lotfi's survey and contextualization of Aghlabid monumental and funerary epigraphy. These articles offer important updates and correctives to the analyses of Marçais, Creswell and Golvin based on recent archaeological excavations and re-analysis of the relevant texts as well as new understandings of the mobility of artisans and materials.

Faouzi Mahfoudh presents a diachronic history of the Great Mosque of Kairouan and unravels a dense web of textual and archaeological evidence to elucidate which elements 
were constructed by the Aghlabids and their predecessors and what function their form might have served. The following essays focus in on particular interventions in the mosque's decoration, remaining in the zone around the mihrab. Jonathan Bloom's study looks to the carved marble panels, some of them openwork, that line the interior of the mihrab niche. Highlighting the recent discovery of a craftsman's signature that includes the nisba 'alAndalusi', he reconsiders the stylistic associations that previous art historians have made with Umayyad art in Syria or early Abbasid art in Iraq, and suggests looking instead to a more local source, al-Andalus. The mid-9th-century Puerta de San Esteban at the Great Mosque of Córdoba offers parallels in the use of marble, carved inscriptions and stylistic motifs to those seen in the Kairouan mihrab. Since such pure white marble is not a raw material available in Ifriqiya, he considers that the marble material could have been imported from al-Andalus and perhaps carved locally, by an expert artisan who also hailed from al-Andalus, though there remains the possibility that the panels were a commission from Córdoban craftsmen and were imported ready-carved, as a parallel to the import of the Abbasid lustre tiles. As such the article argues for a more locally regionalist approach to understanding the creation of one of the most significant examples of carved marble to survive from the 9th century, from anywhere in the Islamic world.

Nadège Picotin and Claire Déléry take the mosque's Aghlabid minbar as their focus, but look to its more recent history. They note that photographs of the minbar from the end of the 19th century, when it was first published by Henri Saladin, compared with more recent photographs show significant differences; at the same time, occasional plaques from the minbar have been removed at certain points and entered the collections of museums in Tunisia and France. The minbar's current backrest bears an inscription with the date of 190910. These early 20th-century interventions have not been well-documented, and the authors make a detailed study of unpublished photographs taken at different dates, and unpublished archival material, including correspondence from some of the great names in the foundation of Islamic art history, Ernst Kuhnel and Josef Strzygowski among them. They offer a preliminary reconstruction of the recent restoration history of the minbar and dispersal of some of its plaques, pending a more detailed study when further access to archives and museum documentation in Tunis or Kairouan can be obtained.

Khadija Hamdi also looks to the Kairouan mosque's minbar to see if it offers clues to the dating and context of a set of mysterious green and yellow tiles that have been installed at some as-yet-unknown date on the wall behind the minbar's backrest. These tiles only came to light in 2010 when the minbar was pulled forward for a new restoration. Never previously mentioned in the literature on the Kairouan mosque, Hamdi considers the possible parallels for these tiles, within the context of Aghlabid ceramics and architectural ornament, as well as the possibility that they represent a more modern intervention in the mosque. Until scientific analyses of these tiles can be arranged, her remarks remain preliminary, but bring to light for the first time a new facet of this mosque's history. Both this paper and that by Picotin and Déléry implicitly reflect on the continuity of local craft traditions within Tunisia across the centuries. 
Rounding out the focus on monuments are two essays on the splendid Zaytuna Mosque of Tunis which is perhaps less familiar to Anglo-Saxon scholars than the Kairouan Mosque, but as a nearly contemporary major monument deserves much more attention. Abdelaziz Daoulatli's essay presents a summary of part of the author's important 1996 publication on the Zaytuna mosque which, though available in reprinted editions, is difficult for scholars outside Tunisia to access. ${ }^{53}$ Daoulatli draws on his extensive knowledge of the textual and archaeological sources for the mosque's long history. He presents proposals for reconstructing the Aghlabid-era form of the mihrab, its southeast minaret, and an explanation for its skewed plan. Sihem Lamine's essay also focuses on the Zaytuna mosque in Tunis, analyzing the specific contexts for its architectural, epigraphic, ornamental, and architectonic features. She argues that the Zaytuna simultaneously exemplifies the emulation of a compelling archetype - the Great Mosque of Kairouan - and a single-minded expression of Tunis' self-assertion and defiance.

Lotfi Abdeljouad's essay is a welcome analysis of Aghlabid epigraphy, which updates our knowledge of the evolution of Kufic inscriptions in the Islamic West. Working from a corpus of 160 architectural and funerary inscriptions, the essay seeks to define the formal characteristics of Aghlabid inscriptions, and to contextualize these in their broader Islamic contexts, both with respect to the Abbasid east as well as in the western Mediterranean. Looking beyond the realm of religious architecture, the Aghlabid coastal fortresses stand out as major early representatives of the building type known as ribat. Ahmed El -Bahi's contribution is the first attempt to make an inventory of the so-called 'Aghlabid' coastal fortifications and to distinguish between those that can be securely dated to the ninth century and those that are less certain in the absence of archaeological evidence. Building on the work of Neji Djelloul, ${ }^{54}$ he shows that many fortifications attributed to the Aghlabids were founded by the Fatimids and Zirids.

\section{Ceramics: morphology and mobility}

This section offers a series of papers presenting focused studies of ceramics from different sites across this region, which date from the 9th to early 10th centuries. Many of these studies raise similar questions regarding the origins of new shapes and techniques, and resort to a common model of "borrowings" from the Islamic East. The widespread export of Abbasid ceramics, especially lustrewares, is credited with spreading an "international Abbasid style" across the Islamic empire, giving rise to new forms and types of decoration, though these might be locally interpreted in different ways. In North Africa, figurative decoration was less popular than in Iraq or Khurasan, and the designs on yellow-glazed wares from Raqqada usually feature birds rather than the human forms common in ceramics attributed to Nishapur. With regard to the yellow-glazed wares - the "jaune de Raqqada" and "giallo di Palermo" - the research currently being undertaken by Oliver Watson might eventually allow us to construct a more nuanced model, in which the "yellow-glazed family" had a much

\footnotetext{
${ }^{53}$ Daoulatli, al-Zaytuna.

${ }^{54}$ Djelloul, al-Ribātāat al-bahrīya
} 
broader geography of production than has hitherto been acknowledged, and that possibly an eastern Mediterranean technology, developed in the 7th or 8th centuries, might provide the common denominator between far western and far eastern manifestations. ${ }^{55}$ And we must not neglect the regionally specific factors: the possible continuities and "borrowings" from Roman, Late Antique and Byzantine forms and technologies, already widely practised in this region, which might be manifest in similar shapes being seen in Spain and Sicily, for example.

Several of these essays also posit a "grande mobilite d'artisans", suggesting that these new forms and aesthetics were spread by means of the potters themselves travelling from place to place. If so, they do not seem to have carried their technologies with them: though the appearance for white-glazed wares in the central and western Mediterranean may indeed reflect a fashion for a new innovation emanating from the imperial centre, scientific analysis on Sicilian ceramics shows that they did not use tin in their glazes, as they did in Iraq. However, true comparative studies cannot yet be undertaken because of the differing levels of scientific analysis: sadly, none have yet been undertaken on the white-glazed wares found at Raqqada. The Sabra ceramics have been analysed but not yet published. When they are, these might show technical continuities from the Aghlabid period into the Fatimid, but without the analyses of Aghlabid ceramics we cannot tell. An important future project would be to conduct comparative scientific analyses of glazed ceramics from Morocco, Tunisia, Sicily, al-Andalus, Egypt and Iraq, across examples dating from 9th, 10th and 11th centuries. This would truly begin to elucidate the spread of technologies from place to place.

Turning to the articles themselves, Soundes Gragueb focuses on the ceramics excavated from the Aghlabid palatine city of Raqqada, occupied between 868 and 921. She presents a morphological and stylistic study of the ceramics found there, focusing on unglazed, yellow-glazed (the characteristic "jaune de Raqqada") and white-glazed wares; she does not discuss the lustrewares found at the site. Reviewing the different forms and their decoration, she attempts to place Raqqada's ceramics within the wider international context of Islamic ceramics at this period, arguing for close connections with the productions of the Islamic East. While forms and appearance - including the adoption of yellow and white glaze grounds - apparently imitate wares from further east, the decoration expresses a more local aesthetic, employing epigraphy, or birds rather than the human figure. These styles may have spread through the circulation of objects throughout the Abbasid empire, or with the movement of the craftsmen themselves. There are also regional connections to be taken into account: the epigraphic decoration of Raqqada's whitewares, employing the phrase "al-mulk" and its variants, closely relates to caliphal ceramics from al-Andalus, but it is important to remember chronology here and that the Aghlabid wares came first. Gragueb also notes that

\footnotetext{
${ }^{55}$ Oliver Watson's current research is focusing on this issue: see his recent article "Revisiting Samarra". Nevertheless, the technologies do not seem to relate: the yellow in the ceramics from Ifriqiya has been analysed and shown to derive from iron in a lead-based glaze (see the article by Soundes Gragueb), while the analysis undertaken by Oliver Watson, Mike Tite and Moujan Matin is finding that the yellow in Eastern Mediterranean ceramics includes tin.
} 
among the unglazed ceramics, forms are shared with Spain and Sicily and have a common origin in Late Antique ceramics.

Very close parallels exist between the ceramics produced locally in Ifrīqiya and those produced contemporaneously in Aghlabid Sicily. Not much material evidence exists for the Islamic presence in Palermo, but archaeological finds in recent years have uncovered interesting ceramics that shed light on the connections between Ifriqiya and its colony in Sicily, as well as processes of Islamicisation on the island. ${ }^{56}$ The paper by Fabiola Ardizzoni, Elena Pezzini and Viva Sacco introduces broad issues of the archaeology of Aghlabid Palermo, and an overview of the ceramic finds and what they can tell us about processes of urban expansion in the ninth and tenth centuries. Focusing on the assemblages discovered during the excavations in the church of "Santa Maria degli Angeli alla Gancia" and in the Bonagia Palace, both situated in the "Kalsa" quarter, near the port, they argue that there was a significant expansion of the city in the late ninth century in the harbour area. Their analysis of the tableware and lamps, cooking wares and amphorae shows strong trading and cultural links between western Sicily and North Africa in the Aghlabid and early Fatimid periods visible in imports from Ifrīqiya and the similarity of certain ceramic forms. They suggest that the new forms, decorations and techniques and the increase in the volume of production can only be explained by significant population movement, demographic growth and an expanding urban market.

Lucia Arcifa and Alessandra Bagnera focus on the case study of Castello San Pietro, near the Aghlabid port of Palermo. Datable between the late 9th and early 10th century it is, together with La Gancia, discussed in the previous article, one of the earliest Islamic settlements so far identified in Palermo. The article discusses its ceramic assemblage, highlighting markers of Islamicisation such as glazing technologies and new shapes, themselves indicative of new systems of lighting, water management and dining practises. Petrographic analyses allow local products to be distinguished from North African imports, though in the absence of comparative analysis for the North African ceramics it is difficult to be more precise about their origins. In particular, the "giallo di Palermo" shows a direct connection, in both shapes and decoration, with the "jaune de Raqqada", and implies a common cultural background for both workshops, or some other direct link between them. At the same time, the authors see an echo of trends in wider Islamic ceramics, in the decoration of a Palermitan cup which appears to imitate the roundels commonly found on the backs of Abbasid lustre bowls; and in the use of opaque white glazes, formed from bubbles and large quartz inclusions in a lead-based glaze without tin, which may attempt to imitate Abbasid tinglazed whitewares. While no such Abbasid vessels have been found archaeologically in Ifriqiya, the authors argue that Abbasid ceramics spread a decorative language around the Islamic world, and Egypt's role in disseminating these wares into the Mediterranean may have been fundamental if little documented. The authors caution against thinking of Ifriqiya as the sole point of reference for Islamic Sicily's ceramic production, and also revise the dominant view that al-Andalus played a significant role in this production.

\footnotetext{
${ }^{56}$ See most recently, Nef, Medieval Palermo.
} 
While there seems to be a strong degree of consistency and connectivity between the ceramics produced in Ifriqiya and Sicily, possibly deriving from shared imports from the East (or shared artisanal expertise), the articles on ceramics from the western Maghrib and alAndalus show a different process at play, one of more regionally specific interaction. The following two articles support the view that connections between this region and the central Mediterranean zone of Ifrīqiya/Sicily are few, at least in regard to the types of ceramics produced at this period. Fez in the early medieval period remains very little studied, and the paper by Kaoutar Elbaljani, Ahmed Ettahiri and Abdallah Fili presents the ceramic assemblages found during restorations in 2006 beneath the prayer hall of the city's alQarawiyyin mosque. Never previously the subject of a scientific and stratigraphic excavation, this intervention has revealed extremely rich and interesting material, including examples of carved architectural plasterwork that appear to come from the mosque's original 9th-century mihrab. ${ }^{57}$ The excavations also uncovered houses dating from the Idrīsid (early 9th century) and Zenata (early 10th century) periods, and the domestic ceramics from these contexts are presented here from the point of view of their technology (revealed through scientific analyses), morphology and decoration. This study thus offers a chronological system upon which to build future research into the ceramics of early medieval Morocco, but also reveals the importance of Fez as a ceramic production centre at this early period, when it was beginning to flourish culturally and economically. Scientific analysis of the clay fabrics has revealed the use of local clays for most of the wares, with cooking pots and casseroles being imported from rural environments within the Moroccan hinterland. The links adduced mainly in shape and type - are to other Moroccan centres, such as Volubilis/Walila, or in some cases to al-Andalus.

Finally, Elena Salinas and Irene Montilla consider the evidence that material culture provides for exchange between al-Andalus and North Africa during the Aghlabid period. Sailors who moved between Iberian and North African coastal cities maintained Aghlabid connections, and were thus one means by which goods circulated between the Aghlabids and neighboring cities. While there do seem to be connections between these two territories, which are more manifest in architecture and epigraphy, evidence of direct exchange is difficult to discern in ceramics and other media. This again supports the notion of indirect exchanges at the level of daily life, or perhaps a preference for more prestigious wares from the Islamic lands to the East. Similarly, evidence from the emirate of Nakur - discussed by Cressier in section 4 - indicates a primarily local western Mediterranean economy for tinglazed ceramics decorated with green-and-brown in the tenth century. Close political contacts between al-Andalus and the Maghribi states during the rise of the Umayyad caliphate in the early 10th century provide a context for the wares found at Nakur, whose port was important for crossing the short distance by sea; nevertheless, the western Mediterranean at this period seems to be characterised by the circulation of primarily local goods within the region.

\section{4. 'Neighbours': North Africa and the central Mediterranean in the 9th century}

\footnotetext{
${ }^{57}$ See Lintz, Déléry and Leonetti, Le Maroc médiéval, 118-20, 193-5, cats. 30-33, 98-100, 103-110.
} 
In the ninth century, the Aghlabids and their neighbours- the Rustamids, Idrīsids, Tulunids, the Umayyads in al-Andalus and a plethora of smaller statelets - were negotiating and transforming definitions of Islamic statehood and rulership, and the very nature of what it meant to be a member of the Muslim community. The essays in this section place the Aghlabids in their North African and central Mediterranean context. Collectively, they show the value of integrating archaeological and historical evidence to unravel the history of early medieval North African states and their links with the Aghlabids and the broader Islamicate world.

Renata Holod and Tarek Kahlaoui examine the relationships between the island of Jerba, an Ibādī stronghold and the Aghlabid mainland. At the start of the $9^{\text {th }}$ century, the Aghlabid dynasty was particularly active in establishing a defensive line of the forts (ribāts) along the coast of Ifriqiya, including a major ribāt located to the north on the mainland at Gabès. Drawing on the results of the Jerba Archaeological Survey conducted between 19962000 and a close reading of the local manuscript tradition, they argue that while at least three forts were operational in the ninth century, none can be directly connected to broader Aghabid fortification initiatives. Indeed, they make a strong argument that the significant changes visible in the settlement pattern in the eighth-tenth centuries reflects the influx of Ibādī settlers in the ninth century attested by local sources. ${ }^{58}$ Further, they suggest that the island was riven by factional disputes between Wahbī and Nukkār factions of the Ibādī, and served as a place of refuge or exile. The Jerba they depict was outside the Aghlabid orbit militarily, commercially and religiously - and would remain so.

Lorenzo Bondioli's essay focuses on Muslim-Christian interactions in the quasiindependent amirate of Bari, on the southern Italian mainland. This case is particularly welldocumented because it came to play an important role in the political history of 9th-century southern Italy, in a context of the political fragmentation of the Lombard principality of Benevento in the face of Carolingian expansion from the north, and competition over Sicily between the Aghlabids and Byzantines. Using a combination of Arabic and Latin sources, Bondioli revisits the date of the amirate's foundation, reassigning it to circa 840 from the established date of 847 , and discusses the close relationship of Bari's rulers with the prince of Benevento, whom they served as mercenaries. In contrast, they seem to have enjoyed less agreeable relations with the Aghlabids, and appealed on several occasions to the caliph in Baghdad for recognition in their own right. He argues that, as a catalyst for Byzantine reengagement in southern Italy and the resultant conflict between the Carolingians, Byzantines and Aghlabids, Bari has assumed a historical importance than went well beyond its actual economic and political significance in the ninth century.

The remaining chapters turn to consider some of the North African neighbours and rivals of the Aghlabids. Patrice Cressier examines the neglected 'emirate' of Nakur, the earliest autonomous state in the Maghreb and the only one to have held to a strictly Sunni Islam. Through a close analysis of the historical resources, he relates the history of this

\footnotetext{
${ }^{58}$ For full results of the survey, see Fentress, Drine and Holold, An Island Through Time: Jerba Studies, vol 1; volume 2 on the medieval results is eagerly awaited.
} 
dynasty and the foundation of the town of Nakur. Very little is known about the archaeology of the town of Nakur beyond the survey and small-scale excavations conducted in the 1980s: the town has two substantial walls, a possible mosque, and a possible hammam; the ceramics reveal connections with Ifriqiya and al-Andalus as well as local productions. It was endogenous rather than exogenous interests that brought about a convergence of interests between two tribal groups (the Banu Waruagal and the Timsaman) and an outsider (Șālih ibn Manșūr of Hymarite descent) to form a state and found a city. As Cressier puts it, Nakur is important because it shows "la coexistence de deux structures politiques fonctionnant en symbiose, une dynastie aux prétentions orientales - origine qui est censée lui apporter sa légitimité - et une mosaïque tribale qu'il s'agit de fédérer sous un gouvernement unique ; une société, en somme, qui parvient à un équilibre efficace entre « arabité » et «berbérité » (avec les guillemets qui s'imposent). ${ }^{59}$

As Elizabeth Fentress shows in her contribution, Walīla (Volubilis) and the origins of the Idrīsid state provides another example of symbiosis between old "Berber" and new "Arab" populations in the making of new states in the early medieval North Africa. The sources relate that one Idris arrived at this important Berber town in 788 fleeing persecution in Baghdad, married a local Berber woman of the Awraba tribe and was proclaimed imam (for the Awraba had already converted to Islam). She suggests that incorporating a descendant of the prophet into their community, the Awraba instantly acquired prestige and legitimacy. Drawing on the excavations of 2000-2005, Fentress reconstructs the plan of Idrīsid Walīla and shows that there were significant distinctions in architecture, house plan and consumption practices between the Berber settlement and what they identify as Idrīs' headquarters outside the walls: an elite complex with Eastern-style courtyard housing, a hammām and a granary. Importantly, the essay highlights the way that Idris I, his burial place and his memory continued to be appropriated and re-appropriated at key points by later Moroccan dynasties seeking to legitimise their rule by linking themselves to the 'Alids and the Prophet.

Chloe Capel offers a critical re-reading of al-Bakri's description in the al-Masâlik wal-Mamâlik of the Midrarid foundation of Sijilmasa in the ninth century. She makes a strong argument for reading al-Bakri's account of the construction of walls by al-Yasa in 199/814-5 as denoting the construction of a new, second, city near to the existing one in the Tafilalt plain, rather than simply as the monumentalisation of the existing one. The archaeological site of Sijilmasa today is this second, royal foundation which was laid out at the same time as a large irrigation channel cut from the Wadi Ziz. ${ }^{60}$ Far from the epicentre of Aghlabid power though it was, she shows that al-Yasa's foundation of Sijilmasa can only be understood within a regional framework of competing and antagonistic early Muslim states in North Africa. It fits within the pattern of royal foundations outside existing urban centres, as at Aghlabid al- 'Abbāsiyya founded outside Kairouan in 184/800 and the Idrīsid imitation of al-'Aliya founded outside the original nucleus of Fes.

\footnotetext{
${ }^{59}$ Cressier, this vol, [crossref]

${ }^{60}$ See now Messier and Miller, The Last Civilised Place.
} 
Finally, David Mattingly and Martin Sterry examine the complex relations between the eastern Sahara and Ifrīqiya in this period. Countering earlier scholarship which argues both for the medieval origins of trans-Saharan trade and an Ibadi-led urbanization of the oases, they remind medieval scholars that there is significant archaeological evidence for the exploitation of the oases of the Libyan Fazzan and a complex regional trading system as early as the early first millennium AD. Their main focus, however, is the rise of Zuwila as the most powerful regional centre in the medieval period at the expense of Jarma, the centre of the Saharan kingdom of the Garamantes until at least the $6^{\text {th }}$ century AD. A combination of excavation, remote-sensing, field survey and radiocarbon dating allows them to reconstruct a Saharan landscape in flux between the seventh-tenth centuries with significant reorganisation of existing oasis settlements in response to the changing political climate, shifting trading routes and the exhaustion of water sources. Zuwila was the winner in this scenario: it had already become the main conduit for trade in sub-Saharan goods and slaves by the time of the first Muslim raids of the Fazzan and in the tenth century it became the centre of the Banu Khattab state. Importantly, this essay shows that we must not assume that the Ibadi and other Berber groups were responsible for establishing trans-Saharan trade: their activities in the desert oases in the late eighth and ninth centuries built on pre-existing networks, which still need to be unraveled for other regions of the Sahara.

\section{$\underline{\text { 5. Legacy }}$}

The volume's last two essays both take a particular Qur'an manuscript as their focus, both dating from the 10th century but revealing different aspects of the continued legacy of the Aghlabids in the Fatimid period. Cheryl Porter's focus is the famous so-called 'Blue Qur'an'. This magnificently produced Qur'an has been the subject of some scholarly debate in recent years, in particular over its origins - whether produced in the Abbasid imperial heartland or in Kairouan, which was an internationally respected centre of religious learning and book production. Porter's article is not intended to argue for one provenance or the other, but to study the manuscript from the perspective of materials and techniques. Having engaged in close physical analysis of several of the manuscript's dispersed folios, she has also conducted empirical research into the means of colouring parchment, applying gold in shell or leaf form, the type of ink used, and what other pigments were employed in its illumination. Not only does this help us to understand the construction of such a precious object and to appreciate the skills of the book craftsmen, but it provides a strong basis on which to build further studies, ideally a comparative analysis of manuscripts known to have been produced in Ifrīina and Iraq.

Jeremy Johns closes the volume with a detailed investigation into the religious context in which the Palermo Qur'ān was produced: dated by its colophon to 982-3 AD, he describes it as the "single most important artifact so far known to survive from Muslim Sicily". But the circumstances of this Qur'an's production have been hitherto misunderstood, and it has been classed as a Fatimid object. Through a codicological analysis, Johns shows that the text of the Qur'an follows the reading favoured by Maliki jurists; indeed, the Palermo Qur'an offers the first material evidence of this. The inclusion in the colophon of the creed 
that the Qur'an was not created leads to a discussion of the debate (mihna) that thrived during the Aghlabid period over the doctrine of the created Qur'an. Johns looks to examples of Aghlabid epigraphy which accept or reject this same creed, arguing that its use or absence stems from political statements over alignment with or opposition to the official dogma advocated by the Abbasid caliph and followed by the Aghlabid emirs, but which was not widely accepted by the Ifriqiyan religious class. The Palermo Qur'an offers the evidence that this controversy must have spread to Sicily, and though produced several decades after the fall of the Aghlabids, it indicates that the island remained staunchly Maliki, even in the face of the Fatimid takeover. This essay, like all the others in this volume, seeks to situate the Aghlabids and their neighbours within their international context. 


\section{Note}

All dates are CE unless otherwise stated.

Spellings follow XXXX

Explain what we have decided about spellings, in light of the fact that we are effectively merging a Francophone and an Anglophone academic system. 